\section{Huono-osaisuuden kasautuminen nuoruudesta keski-ikään}

Stakesin entinen pääjohtaja Vappu Taipale on usein todennut vanhojen ihmisten olevan kerroksellisia. Vanhan ihmisen sisälle on ehtinyt kertyä useita elämän varrella muovautuneita kerrostumia. Vanha ja vireä -kirjassaan (1) hän kertoo, miltä kerroksellisuus tuntuu. Hän sanoo: Koen olevani se lapsi, joka eli varhaisen lapsuutensa sodan varjossa, se nuori, jonka nuoruus meni 1950-luvun niukkuudessa ja se 1960-luvun radikaali opiskelija, josta tuli neljän lapsen äiti. Sitten seurasi valmistuminen lääkäriksi, yhteiskunnalliset vastuutehtävät, hektinen työelämä ja lopulta isoäitiys, onni olla seitsemän lapsenlapsen mumma.

Elämänkulkututkimus pyrkii tarkastelemaan näitä ihmisen elämän eri kerrostumia ja sitä, miten aikaisemmat kerrostumat ovat muokanneet myöhempiä. Ensimmäiset elämänkulun tutkimukset käynnistyivät Yhdysvalloissa 1910- ja 20-luvuilla (2), mutta vasta viime vuosikymmeninä tämä tutkimusperinne on kasvattanut suosiotaan (3) ja pitkittäisaineistot ovat mahdollistaneet ihmisen elämän seuraamisen läpi useiden ikävaiheiden. Elämänkulkututkimuksen teoreet- tiset ja menetelmälliset juuret ovat toisaalta ihmisen biologisen ja toisaalta psykologisen kehityksen teorioissa ja tutkimuksissa. Elämänkulkututkimusta kehitettiin yhdistämällä näitä periaatteita ihmisen biologisesta ja psyykkisestä kehityksestä sekä tuomalla aiempaa voimakkaammin esiin myös kehityksen sosiaalinen ulottuvuus. Elämänkulkututkimuksen keskeisiä lähtökohtia on ihmisen elämän hahmottaminen kokonaisuutena ja eri elämänvaiheiden summana.

Suomi on pitkittäistutkimusten luvattu maa. Meillä ihmisten tavoittaminen on helppoa henkilötunnuksen takia. Yksi pisimmistä suomalaisista pitkittäistutkimuksista on Jyväskylän yliopistossa 1960-luvulla professori Lea Pulkkisen aloittama tutkimus Lapsesta aikuiseksi (4). Siinä on tutkittu samoja ihmisiä jo yli 40 vuotta. Maailmalla pisin ihmistutkimus on jatkunut jo yli 90 vuotta. Päättymässä oleva tutkimus alkoi vuonna 1921, kun Lewis Terman Stanfordin yliopistosta ryhtyi keräämään tietoa noin 1500 lahjakkaasta lapsesta, jotka syntyivät 1900-luvun alussa (5). Tutkimus kestää tiettävästi niin kauan kuin yksikin tutkittava on elossa. Terman itse kuoli vuonna 1956, mutta muut tutkijat ovat jatkaneet hänen työtään.

Pitkittäistutkimuksille olisi yhä enemmän tarvetta, mutta aineistot karttuvat hitaasti ja tällainen tutkimus edellyttää sitoutumista. Pitkittäistutkimus- ten haasteena voidaan nähdä myös se, että pitkittäistutkimuksia suunnittelevien tutkijoiden tulisi osata nähdä tulevaisuuteen. Ne mittarit, jotka vuosikymmeniä sitten olivat muotia, saattavat 2010-luvulla olla auttamatta vanhentuneita. Kun tutkitaan muutosta, olisi kuitenkin tärkeää pitää tutkimuksen menetelmät hyvin samankaltaisina eri ikävaiheissa.

Elämänkulkututkimukseen liitetään yleensä viisi lähestymistapaa tai periaatetta (2). Ensiksi ihmisen elämä ja kehittyminen ovat elinikäisiä prosesseja eikä kehitys pysähdy, kun saavutetaan aikuisuus. Kehityksellä voidaan tässä yhteydessä tarkoittaa asioiden sekä positiivista että negatiivista kehitystä (6). Toiseksi kehitys tapahtuu tiettyyn aikaan ja paikkaan sidottuna. Esimerkiksi eläminen ja kehittyminen Suomessa 2000-luvulla on erilaista kuin vaikkapa Kiinassa 1960-luvulla. Kolmas periaate korostaa toimijuutta. Ihminen itse toimii aktiivisesti ja tekee valintoja niissä olosuhteissa, joissa hän elää. Neljänneksi ihmisen elämänkulku ei ole irrallinen, vaan se on vahvasti yhteydessä muiden ihmisten elämänkulkuun. Esimerkiksi nuoren irtautuminen lapsuuden perheestä ja muutto omaan kotiin vaikuttavat myös vanhempien elämänkulkuun ja siirtymiin. Viides lähestymistapa kiinnittää huomiota elämänkulun siirtymien, tapahtumien ja käyttäytymisen ajoittumiseen. On eri asia sairastua masen- 
nukseen 16-vuotiaana kuin 70-vuotiaana. Samoin työttömäksi joutumisella on erilainen merkitys nuorille, jotka ovat juuri valmistuneet ammattiin, kuin henkilöille, jotka ovat jäämässä eläkkeelle.

On monia kulttuurisesti määrittyneitä tapoja kuvata elämänkulkua ja jaotella erilaisia ikävaiheita. Elämänkulkua on perinteisesti kuvattu ympyränä, kaarena tai etenevänä viivana, lisäksi mm. puu, polku ja virta ovat tyypillisiä metaforia (7). Ympyrä-metaforaan liittyy ajatus syklisestä aikakäsityksestä ja elämänvaiheiden ikuisesta kierrosta. Kaari-ajattelussa ihmiselämää symboloi ensin kasvu ja sen jälkeen kuihtuminen. Tässä näkökulmassa aikuisuus näyttäytyy kehityksen huippuna ja muut elämänvaiheet nähdään vähempiarvoisina. Elämänkaari-termin käyttö on edelleen hyvin yleistä, etenkin psykologian alalla, vaikka siihen - tuskin ainakaan tietoisesti - halutaan liittää näin voimakasta arvolatausta.

Nykyään etenevä viiva metafora on kaikkein yleisin tapa hahmottaa elämänkulkua. Siinä elämänvaiheet on asetettu ajalliseen järjestykseen ja elämänkulku etenee ilman laskua joko aikajanana tai lineaarisesti nousevana (7). Viittaukset elämään polkuna kuvaavat ihmisen yksilöllisempää kulkua elämäntaipaleella, jossa ihminen on matkalainen. Polku, jota hän kulkee, voi olla suora, mutkainen ehkä kivinenkin. Polun muodosta riippumatta ihminen nähdään tässä metaforassa aktiivisena kulkijana.

Yhteistä kaikille näille metaforille on se, että elämän kuluessa ihminen siirtyy elä- mänvaiheesta toiseen, kuten Taipalekin kirjassaan kuvasi (1). Elämänvaiheesta toiseen siirtyminen määrittyy monien eritasoisten tekijöiden ja tapahtumien kautta. Kehityspsykologi Paul Baltes työtovereineen $(8,9)$ jakoi elämään liittyvät muutokset kolmeen luokkaan. Niin sanotusti normatiivisia iänmukaisia elämäntapahtumia ovat tietyt biologiset ja ympäristöön liittyvät tekijät, jotka ohjaavat ihmisen elämää kronologiseen ikään ja ikänormeihin perustuen. Tällaisia tapahtumia voivat olla esimerkiksi puberteetin alkaminen tai koulun aloittaminen. Normatiivisia historiaan liittyviä tapahtumia puolestaan ovat esimerkiksi sotaan osallistuminen tai lama-aikana työmarkkinoille siirtyminen eli tapahtumat, jotka ovat tyypillisiä tietylle sukupolvelle. Lisäksi elämänkulkuun voivat vaikuttaa yksilölliset ei-normatiiviset tapahtumat kuten vakava sairastuminen tai vaikkapa lottovoitto.

Näihin elämän siirtymiin sisältyy mahdollisuus jatkuvuuteen ja muutokseen. Sujuuko siirtyminen päiväkodista ja kotoa peruskouluun, sieltä ammatilliseen koulutukseen ja siitä eteenpäin työelämään sujuvasti vai katkeaako polku jossain kohtaa? Esimerkiksi yksilön kohtaama työttömyys saattaa pitkittää mahdollisuuksia aloittaa itsenäinen elämä varhaisaikuisuudessa. Elämänvaiheiden erot ja rajapinnat eivät siis ole pysyviä. Polut ja siirtymät elämänvaiheista toisiin ovat myös vuosien aikana muuttuneet. Varhaisaikuisuus on pidentynyt ja mahdolliset polut aikuisuuteen ovat monimutkaistuneet. Ei ole nykyään itsestään selvää, mitä aikuisuus on. Vakiintuneet polut työelämään siirtymisestä ja perheenperustamisesta ovat saaneet rinnalleen uusia mahdollisia polkuja. (10)

Näihin elämän eri vaiheisiin ja Taipaleen kuvaamiin kerrostumiin tiivistyy myös ihmisen hyvinvointi ja toisaalta huono-osaisuus. Voidaan ajatella, että hyvinvointi ja huono-osaisuus ovat rakentuneet ihmisen aikaisemman hyvinvoinnin ja huono-osaisuuden varaan. Hyvinvointi tuottaa hyvinvointia myös myöhemmässä elämässä ja toisaalta huono-osaisuus herkemmin lisää huono-osaisuutta jatkossakin - huono-osaisuus kasautuu.

Henkilöllä voi esimerkiksi olla vähän rahaa käytettävissään, mutta hyvä terveys. Vaikka terveys olisi kuinka hyvä, se ei kuitenkaan poista köyhyyden aiheuttamia taloudellisia vaikeuksia. Samalla tavoin toisella henkilöllä voi olla heikko terveydentila, mutta paljon varallisuutta. Vaikka varakkaalla ihmisellä on ehkä paremmat mahdollisuudet hankkia sairauteensa hoitoa, raha ei kuitenkaan korvaa terveydellisen tilanteen aiheuttamaa haittaa. Molemmat henkilöt voivat kokea huono-osaisuutta, mutta eri tavoin.

Perinteisesti huono-osaisuus on mielletty köyhyytenä. Kuitenkin jo useita vuosikymmeniä sitten on ajateltu, että huono-osaisuutta voi esiintyä useilla eri elämän ulottuvuuksilla $(11,12)$. Se voi kohdistua esimerkiksi terveyteen, sosioekonomisiin oloihin tai sosiaalisiin suhteisiin. Eivätkä eri ulottuvuudet sulje toisiaan pois. Huono-osaisuuteen on myös 
liitetty tietynlaisia elämäntyyliin liittyviä asioita kuten rikollisuus tai runsas alkoholinkäyttö $(13,14)$. Voidaan ajatella niin, että huono-osaisuutta on vaikea elämäntilanne sinänsä, mutta myös se, että ihminen on suuressa riskissä kokea vaikeuksia (15). Vaikka tämä huono-osaisuuden moniulotteinen määritelmä on nykyään jo laajasti hyväksytty, empiirisesti sen tutkiminen ei kuitenkaan ole ollut yleistä. Tapana on ollut tutkia joidenkin ulottuvuuksien välisiä yhteyksiä, tyypillisesti esimerkiksi terveyden ja sosioekonomisen ulottuvuuden suhdetta. Tutkimukset, joissa huono-osaisuutta olisi tutkittu muutamaa ulottuvuutta laajemmin, ovat harvinaisempia - etenkin sellaiset tutkimusasetelmat, jossa samalla huomioitaisiin huono-osaisuuden kehitys läpi elämän.

Huono-osaisuus on käsitteenä hankala. Sille ei ole vakiintunutta määritelmää ja siihen saattaa liittyä leima. Jos ihmisiltä itseltään kysytään asiasta, he harvoin mieltävät itseään ainoastaan huonoosaisiksi. Esimerkiksi erään tutkimuksen mukaan päihdeja mielenterveysjärjestöjen toimintaan oman ongelmansa takia osallistuneista suurin osa koki itsensä sekä hyvä- että huono-osaiseksi (16). Huonoosaisuus voidaan nähdä puutteellisina mahdollisuuksina elää tyydyttävää elämää. Se, miten hyvän elämän edellytykset koetaan, on subjektiivista ja se tekee huono-osaisuuden määrittelemisestä vielä haastavampaa. Huono-osaisuudesta puhuttaessa onkin syytä tarkentaa, mihin sillä viitataan.
Huono-osaisuus ei ole yksiön ominaisuus. Lähes kaikki kokevat jonkinlaista huono-osaisuutta elämänsä aikana. Eikä se välttämättä ole pysyvää, vaan voi liittyä tiettyyn elämänvaiheeseen. On esimerkiksi arvioitu, että vähintään joka kolmas, mahdollisesti jopa puolet, ihmisistä kokee elämänsä aikana mielenterveyteen liittyviä vaikeuksia $(17,18)$. Samoin Suomessa on verrattain suuri joukko nuoria aikuisia, jotka eivät ole koulutuksessa, työelämässä tai harjoittelussa. Kuitenkin heistä yli puolet oli siirtynyt koulutukseen tai työelämään seuraavaan viiden vuoden kuluessa (19).

Moniulotteinen pitkittäinen lähestymistapa huono-osaisuuteen vaikeuttaa ilmiön empiiristä tutkimista. Huono-osaisuus ilmenee eri tavoin eri elämänvaiheissa ja samakin huono-osaisuustekijä voi saada erilaisen merkityksen eri iässä, eri elämänvaiheessa. Esimerkiksi ristiriidat lapsen ja vanhemman välillä ovat ihmisen kehityksen kannalta erilaisia elämän varhaisissa vaiheissa verrattuna aikuisen lapsen ja hänen ikääntyneen vanhempansa välisiin ristiriitoihin. Lisäksi useita erityyppisiä ulottuvuuksia kattava ilmiö on hyvin monisyinen ja elämänkulku näyttäytyy suoraviivaisen polun sijaan verkkona, jossa erilaiset tekijät ovat yhteydessä toisiinsa monin tavoin. Huono-osaisuustekijöiden välisiä monimutkaisia yhteyksiä on vaikea tavoittaa empiirisessä tutkimuksessa. Vasta muutaman viime vuosikymmenen aikana tilastolliset menetelmät ovat kehittyneet niin paljon, että näiden monimutkaisten yhteyksien mallintaminen on mahdollista.

Usein ajatellaan, että kaikkein haitallisinta on huonoosaisuus, joka koskettaa monia elämänalueita ja pitkittyy. Huono-osaisuuden kasautumista voidaan tarkastella monella tapaa. Ensinnäkin huono-osaisuuden kasautumisella on tarkoitettu tilannetta, jossa yhden henkilön elämässä on samanaikaisesti läsnä useita erilaisia huono-osaisuustekijöitä. Toisaalta kasautumisella on viitattu tilanteeseen, jossa jokin tietty huono-osaisuustekijä toistuu useissa elämänvaiheissa. Esimerkiksi pitkäaikaistyöttömyys viittaa tämän tyyppiseen huono-osaisuuden kasautumiseen. Kolmanneksi kasautumisella on tarkoitettu ajallista prosessia, jossa yksi huono-osaisuustekijä johtaa toiseen tekijään jollain toisella elämän ulottuvuudella ja se taas johtaa kolmanteen tekijään. Tällöin puhutaan riskien ketjuista. Huolimatta siitä, että pitkittäistutkimuksia on yhä enemmän, tiedämme melko vähän siitä, miten useat eri huono-osaisuustekijät linkittyvät toisiinsa ja kuinka nämä prosessit tuottavat huono-osaisuutta elämänkulussa.

Huono-osaisuuden kasautuminen liittyy vahvasti hyvinvoinnin eriarvoiseen jakautumiseen. 1990-luvun laman aikaan huono-osaisuustutkimuksen sanottiin olevan muodikasta (20) ja viime vuosina termiä käyttäneiden julkaisujen määrä kertoo, että se on edelleen aiheena hyvin ajankohtainen. Viimeisten vuosikymmenten aikana hyvinvointi on lisääntynyt 
Suomessa useilla eri mittareilla mitattuna, mutta edelleenkään se ei jakaudu tasaisesti $(21,22)$. Tämä eriarvoisuus kertoo siitä, että Suomessa ei ole pystytty edistämään kaikkien hyvinvointia tasa-arvoisesti. Julkinen keskustelu huono-osaisuudesta on pääosin keskittynyt taloudelliseen huono-osaisuuteen sekä etenkin huolta on herättänyt nuorten ja nuorten aikuisten työstä ja koulutuksesta syrjäytyminen.

Sukupuoli ei ole ollut aikaisemmissa huono-osaisuustutkimuksissa useinkaan keskiössä. Tiedetään, että tietyillä elämän alueilla sukupuolten välillä on eroja huono-osaisuuden esiintymisessä. Esimerkiksi psyykkinen oireilu on naisilla yleisempää kuin miehillä ja miehet taas juovat alkoholia useammin ja suurempina määrinä kuin naiset $(23,24)$. Lisäksi naiset kokevat saavansa miehiä useammin henkistä tukea sosiaalisista suhteistaan (25). Kuitenkin paljon vähemmän tiedetään siitä, ovatko myös huono-osaisuuden kasautumiseen liittyvät polut erilaisia miehillä ja naisilla.

Väitöskirjassani tutkittiin sitä, miten useilla eri tavoin mitattu huono-osaisuus muotoutuu ja kasautuu yksilöiden elämän aikana nuoruudesta keski-ikään asti. Tutkimus on osa professori Hillevi Aron pitkään johtamaa Stressi, kehitys ja mielenterveys hanketta jossa on seurattu yhtä tamperelaisten koululaisten ikäkohorttia 26 vuotta (26).

Tutkittavat syntyivät pääosin vuonna 1967 ja heidän ikäluokkaansa on kuvailtu hyvinvoinnin sukupolveksi (27). Sillä viitataan aikaan, jolloin suomalaista hyvinvointivaltiota vahvistettiin ja laajennettiin. He elivät nuoruutensa 80-luvulla taloudellisen kasvun aikana ja 90-luvun laman aikaan he olivat nuoria aikuisia, joista osa oli jo siirtynyt työelämään ja osa oli edelleen opiskelemassa. Elämänkulkututkimuksen mukaan yksilöllinen elämä kulkeekin aina käsi kädessä yhteiskunnallisten muutosten kanssa.

Väitöstutkimuksessa tarkasteltiin nuoruusiän huono-osaisuuden kasautumisen yhteyttä kuolleisuuteen. Jatkokoulutussuunnitelmien puuttuminen tai epävarmuus niistä 16-vuotiaana oli yksittäisistä tekijöistä voimakkaimmin yhteydessä kuolleisuuteen ennen 43. ikävuotta. Eri huono-osaisuuksien ulottuvuuksia vertailtaessa voimakkaimmin kuolleisuuteen oli yhteydessä sosiaalisiin suhteisiin liittyvien ongelmien kasautuminen. (28)

Tutkimus osoitti myös, että vaikeudet perheen ihmissuhteissa nuoruusiässä olivat osa riskien ketjuja, jotka ulottuivat keski-iän huono-osaisuuteen saakka. Naisilla polut keskiiän taloudellisiin ongelmiin muovautuivat varhaisaikuisuuden matalan koulutuksen ja mielenterveysongelmien kautta. Miehillä kehitystä muovasi varhaisaikuisuuden koulutus, jonka merkitys selittyi nuoruusiän heikolla koulumenestyksellä. Voidaan ajatella, että miehet, joilla oli vaikeuksia perhesuhteissa nuoruudessa, olivat jo usein nuoruudessaan vaikeampiin tulevaisuuden näkymiin johtavilla urilla, jotka jatkuivat aikuisuuteen. (29) Nuoruusiän perhesuhteiden vaikeuksista keski-iän mielenterveysongel- miin johtava kehityspolku rakentui varhaisaikuisuuden mielenterveysongelmien ja naisilla myös runsaan alkoholinkäytön kautta.

Nuoruudesta keski-ikään usein humalaan juovat naiset kokivat todennäköisemmin lähes kaikkia tarkasteltuja huonoosaisuuden muotoja keskiiässä. He muun muassa kokivat terveytensä ja taloutensa huonommaksi ja olivat todennäköisemmin masentuneita, työttömiä ja eivät olleet aviotai avoliitossa. Humalajuomistaan nuoruudesta lisänneet tai pysyvästi runsaasti juovat miehet kokivat todennäköisemmin terveyden ja talouden ongelmia keski-iässä. Hyvä uutinen on se, että nuoruusiässä usein tapahtuva humalajuominen ei jättänyt keski-iän huono-osaisuuteen johtavaa arpea, jos juominen väheni nuoruusiän jälkeen. (30)

Tutkimuksen tulokset vahvistavat käsitystä siitä, että huono-osaisuutta olisi tärkeää tarkastella paljon laajemmin kuin vain köyhyytenä tai syrjäytymisenä työmarkkinoilta. Lapsuudessa ja nuoruudessa koetulla huono-osaisuudella on pitkäaikainen vaikutus hyvinvointiin ja huono-osaisuuteen aina keski-ikään saakka. Lapsuuden ja nuoruuden olosuhteet kuitenkin harvoin vääjäämättä määrittävät ihmisen elämää, olosuhteilla muissa elämänvaiheissa on merkitystä. Siksi huono-osaisuuden ehkäisytyössä tulisikin paremmin lapsuuden ja nuoruuden olosuhteiden lisäksi hyödyntää myös muissa ikävaiheissa avautuvat mahdollisuudet huono-osaisuuden ketjujen katkaisemiseksi. 
(1) Taipale V. Vanha ja vireä. Virkistyskirja vanhoille naisille. Helsinki: WSOY; 2011.

(2) Elder G, Jr., Kirkpatrick Johnson M, Crosnoe R. The Emergence and Development of Life Course Theory. Kirjassa: Mortimer J, Shanahan M. (toim.) Handbook of the Life Course New York: Springer; 2003, 3-19.

(3) Shanahan M, Mortimer J, Kirkpatrick Johnson M. Introduction: Life Course Studies - Trends, Challenges, and Future Directions. Kirjassa: Shanahan M, Mortimer J, Kirkpatrick Jonson M. (toim.) Handbook of the Life Course. Volume II Switzerland: Springer International Publishing; 2016, 1-23.

(4) Pulkkinen L, Kinnunen U, Kokkonen M ym. (toim.). Lapsesta aikuiseksi. Jyväskylä: Atena; 1996.

(5) Terman L, Oden M. The Gifted Child Grows Up. Standford University Press; 1947.

(6) Baltes P, Lindenberger U, Staudinger U. Life Span Theory in Developmental Psychology. Kirjassa: Lerner R. (toim.) Handbook of Child Psychology. 6. p. New York: Wiley; 2006, 569-664.

(7) Tuomi J. Aetatis hominun - elämänkulun vaiheet antiikin ja keskiajan kirjallisuudessa. Kirjassa: Heikkinen E, Tuomi J. (toim.) Suomalainen elämänkulku: Kustannusosakeyhtiö Tammi; 2001, 13-37.

(8) Baltes P, Reese H, Lipsitt L. Life-span developmental psychology. Annu Rev Psychol 1980;31:65-110. https://doi. org/10.1146/annurev. ps.31.020180.000433

(9) Nurmi J, Salmela-Aro K. Ihmisen psykologinen kehitys ja elämänkulku. Kirjassa: Heikkinen E, Tuomi J. (toim.) Suomalainen elämänkulku: Kustannusosakeyhtiö Tammi; 2001, 86-98.
(10) Aapola S, Ketokivi K. Johdanto: Aikuistumisen ehdot 2000-luvun yhteiskunnassa. Kirjassa: Aapola S, Ketokivi K. (toim.) Polkuja ja poikkeamia - Aikuisuutta etsimässä. 3. p. Helsinki: Nuorisotutkimusseura; 2014, 7-32.

(11) Jonsson G. Det sociala arvet. Folksam: Tidens förlag; 1969.

(12) Rutter M, Madge N. Cycles of Disadvantage. London: Heinemann; 1976.

(13) Waxman C. The Stigma of Poverty. A Critique of Poverty Theories and Policies. New York: Pergamon Press; 1983.

(14) Laub J, Sampson R. TurningPoints in the Life-Course - Why Change Matters to the Study of Crime. Criminology 1993;31:301-325. https://doi org/10.1111/j. 1745-9125.1993.tb01132.x

(15) Wolff J, De-Shalit A. Disadvantage. New York: Oxford University Press; 2007. https://doi.org/10.1093/ acprof:oso/ 97801992 78268.001 .0001

(16) Pitkänen T, Tourunen J. Päihde- ja mielenterveysjärjestöjen toimintoihin osallistuneiden kansalaisten hyvinvointi kahden kyselytutkimuksen perusteella. Kirjassa: Murto J, Pentala O, (toim.). Osallistuminen, hyvinvointi ja sosiaalinen osallisuus - ATH-tutkimuksen tuloksia. Järjestökentän tutkimusohjelma Helsinki: Terveyden ja hyvinvoinnin laitos; 2016, 20-25.

(17) Kessler R, Wang P. The descriptive epidemiologv of commonly occurring mental disorders in the United States. Annu Rev Public Health 2008;29:115-129. https://doi.org/10.1146/ annurev.ublhealth. 29.020907.090847

(18) Steel Z, Marnane C, Iranpour $\mathrm{C}$ ym. The global prevalence of common mental disorders: a systematic review and metaanalysis 1980-2013. Int J
Epidemiol 2014;43:476-493. https://doi.org/10.1093/ije/ dyu038

(19) Myrskylä P. Hukassa - Keitä ovat syrjäytyneet nuoret? EVA Analyysi 19; 2012.

(20) Helne T. Erään muodin tarina - 1980-luvun suomalaisesta syrjäytymiskeskustelusta. Kirjassa: Heikkilä M, Vähätalo K. (toim.) Huonoosaisuus ja hyvinvointivaltion muutos Tampere: Oy Libri Academici Ab / Gaudeamus Kirja; 1994, 32-50.

(21) Talala K, Härkänen $\mathrm{T}$, Martelin T ym. Koulutusryhmien väliset terveys- ja hyvinvointierot ovat edelleen suuria. Suomen Lääkärilehti 2014;69:21852192a.

(22) Tarkiainen L, Martikainen $\mathrm{P}$, Laaksonen $\mathrm{M}$ ym. Trends in life expectancy by income from 1988 to 2007: decomposition by age and cause of death. J Epidemiol Community Health 2012;66:573-578. https://doi.org/10.1136/ jech.2010.123182

(23) Holmila M, Raitasalo $\mathrm{K}$. Gender differences in drinking: why do they still exist? Addiction 2005;100:1763-1769. https://doi.org/10.1111/ j.1360-0443.2005.01249.x

(24) Rutter M, Caspi A, Moffitt $\mathrm{T}$. Using sex differences in psychopathology to study causal mechanisms: unifying issues and research strategies. J Child Psychol Psychiatry Allied Disciplines 2003;44:1092-1115. https://doi.org/10.1111/1469. 7610.00194

(25) Umberson D, Williams K, Thomas P ym. Race, Gender, and Chains of Disadvantage Childhood Adversity, Social Relationships, and Health. J Health Soc Behav 2014;55:20-38. https://doi.rg/ 10.1177/00221 46514521426

(26) Mustonen U, Huurre T, Kiviruusu O ym. Elämänkulku, mielenterveys ja hyvinvointi. 
Seurantatutkimus

16-vuotiaista

tamperelaisnuorista 22-,

32- ja 42-vuotiaina (TAM-

projekti). Helsinki: Terveyden

ja hyvinvoinnin laitos; 2013.

(27) Järvensivu A, Nikkanen

$\mathrm{R}$, Syrjä S. Työelämän

sukupolvet. Tampere:

Tampere University Press; 2014.

(28) Berg N, Huurre T, Kiviruusu O ym. Nuoruusiän huonoosaisuus ja sen kasautumisen yhteys kuolleisuuteen.
Seurantatutkimus

16-vuotiaista nuorista.

Sosiaalilääk Aikak

2011;48:168-181.

(29) Berg N, Kiviruusu O,

Karvonen $S$ ym. Pathways from poor family relationships in adolescence to economic adversity in mid-adulthood. Adv Life Course Res 2016;10.1016/j. alcr.2016.07.001. Painossa. https://doi.org/10.1016/j. alcr.2016.07.001
(30) Berg N, Kiviruusu O,

Karvonen S ym. A 26-year follow-up study of heavy drinking trajectories from adolescence to mid-adulthood and adult disadvantage.

Alcohol Alcohol 2013;48:452-457. https://doi.org/10.1093/alcalc/ agt026

NoOra Berg

FT, tutkijatohtori

Uppsalan yliopisto

\section{5 ST}

Sosiaalilääketieteen yhdistys ry. jakaa ensimmäistä kertaa tunnustuspalkinnon korkeatasoisesta sosiaalilääketieteellisestä pro gradu -tutkielmasta.

Palkinnon suuruus on 200 euroa. Lisäksi voittaja voi halutessaan liittyä yhdistykseen ilman ensimmäisen vuoden jäsenmaksuvelvoitetta ja laatia tutkielmastaan artikkelin Sosiaalilääketieteelliseen aikakauslehteen.

Palkinto myönnetään suomalaiseen yliopistoon tehdystä opinnäytteestä. Tunnustuksen saajan valitsee Sosiaalilääketieteen yhdistyksen hallitus tai hallituksen valitsema henkilö. Palkinto luovutetaan Terveydenhuoltotutkimuksen päivien yhteydessä marraskuussa 2017 Tampereella.

Pyydämme nyt ehdotuksia korkeatasoisista opinnäytteistä, jotka on hyväksytty tiedekunnassa lukuvuoden 2016-2017 aikana (1.8.2016-31.7.2017). Ehdottajana voi olla työn laatija, sen ohjaaja tai muu työhön perehtynyt henkilö. Ehdotukseen tulee liittää opinnäytejulkaisu, siitä annetut lausunnot, perustelut palkinnolle, sekä ehdottajan ja graduntekijän yhteystiedot.

Ehdotukset palkinnon saajaksi tulee lähettää 31.8.2017 mennessä osoitteeseen sihteeri@socialmedicine.fi. Lisätietoja: peija.haaramo@thl.fi. 